\title{
How Can Ibn Khaldun's Economic Philosophy Revive the Intellectual Capital of Entrepreneurs
}

\author{
Sakinah Mat Zin ${ }^{1,2}$, Ahmad Azrin Adnan ${ }^{2}$, Iskandar Hasan Tan Abdullah ${ }^{3}$ \\ ${ }^{1}$ Faculty of Business and Management, University Technology MARA, Kelantan, Malaysia \\ ${ }^{2}$ Research Institute for Islamic Products and Malay Civilization (INSPIRE), UniSZA, Terengganu, Malaysia \\ ${ }^{3}$ Faculty of Administrative Science and Public Policy, University Technology MARA, Kelantan, Terengganu \\ Correspondence: Iskandar Hasan Tan Abdullah, Faculty of Administrative Science and Public Policy, University \\ Technology MARA, Kelantan, Malaysia. Tel: 60-13-518-8618. E-mail: iskandartan@yahoo.com
}

Received: April 20, 2017

doi:10.5539/ass.v13n6p164
Accepted: May 2, $2017 \quad$ Online Published: May 31, 2017

URL: https://doi.org/10.5539/ass.v13n6p164

\begin{abstract}
Ibn Khaldun's magnificent reflections on the economic growth and philosophical insights into the behavior of human beings and society, as well as interrelationships among various disciplines such as politics, economics, sociology and education have reckoned him the outstanding figure in the social sciences and one of the greatest philosophers in the world. A comprehending to Ibn Khaldun's Economic Philosophy and its outcomes for outstanding business performance assists entrepreneurs in managing intellectual capital (IC) purposefully. IC is deliberated as an indispensable factor in an organizational exertion to accentuate on bringing about competitive gains and augmenting value creations in knowledge-based economy. Instead of engaging merely on innovativeness of new products, Small and Medium Enterprise (SME) entrepreneurs must also concentrate on administering IC in accordance to Ibn Khaldun's Economic Philosophy. This paper targets to appreciate and re-examine contributions in Ibn Khaldun's Economic Philosophy and IC in entrepreneurial researches and indicate how Ibn Khaldun's Theory of Development is pertinent to research in the expanse of IC.
\end{abstract}

Keywords: Ibn Khaldun, Intellectual Capital, Knowledge-based, Small, Medium Enterprises

\section{Introduction}

In the era of knowledge-based economy, intellectual assets are regarded as more precious than physical capitals (Powell \& Snellman, 2004). Ramezan (2011) are agreed that the knowledge embedded in individuals and firms are called intellectual capital (IC). Success in business relies on organizational capability to manage and leverage IC towards value creations (Cortini and Benevene, 2010). The concept of IC needs to be understood and managed efficiently by Small and Medium Enterprises (SMEs). This is owing to low SME labour productivity as compared to that of large organizations. SME Annual Report 2013/2014 shows that in 2013, Malaysian SMEs' labour productivity was 2.73 times lesser than that of big firm. According to Bontis (2004) to make the matter worse, labour quality in Malaysia demonstrates a decrease extent for 2006-2012 phases compared to other developed countries like Japan, Finland, Singapore and South Korea). Malaysia has the number of skilful and talented workers which are a smaller amount of than the average of high-income countries (Keenam \& Aggestam, 2001). In general, Malaysia is facing a shortage of skilled workers, frail productivity progress because of less creativity and innovation in the labour force, and an over-reliance on incompetent low-priced foreign employments (Malaysia Productivity Centre (MPC), 2014). Such situations must be tackled effectively so as SME entrepreneurs are safe from being bankrupt ${ }^{8}$. Those symptoms are developed mainly due to the following problems (Bontis, 1999):

1. SME entrepreneurs are oblivious of the function of IC as an important means to upsurge firm performance.

2. SME entrepreneurs do not understand the influence of Ibn Khaldun's Economic Philosophy on IC and their business performance.

Hence, a study is prerequisite to be conducted in an attempt to discover to what extent IC, managed in accordance to Ibn Khaldun's Economic Philosophy, will contribute to increasing competitive advantages in SMEs. Specially, this paper compromises basis to researches on Ibn Khaldun's Economic Philosophy and IC. The first section of this paper starts with the explanation of IC and its impacts to business performance. Then the 
paper endeavors to clarify IC based on Ibn Khaldun's Theory of Development by showing how it is relevant for research in the expanse of entrepreneurial studies.

\section{IC and Business Performance}

IC defines as intellectual materials - knowledge, experience, customer relationships, information, intellectual property, organizational technology, and professional ability that deliver the firm with competitive benefits (Khalique, Isa \& Shaari, 2013). In recent studies, IC sub-domains are classified into five essential elements; human capital, organizational capital, relational capital (customer and social), technological capital and spiritual capital (Ullah \& Hassan Yousaf, 2016).

Human capital is genetic inheritance, experience, education, attitudes (Omar \& Azmi, 2015), ability, the relationship between aptitude and knowledge (Hitti, 1958). It is a vital asset for firm's strategic revitalization and innovation (Sydler, Haefliger \& Pruksa, 2014). Organizational capital is company's intellectual property, corporate values, image and brand, research and development (R\&D), information technology, organization philosophy and process (Saunders, 1966). Previous researchers claim that by multiplying organizational capital, the firm's profitability will be increased (Stewart, 1997). Relational capital refers to the organization's relationship with the outside environment such as alliances, suppliers, customers, partners, competitors and delivery networks. In other words, relational capital represents the organization's relationships with external parties (Jardón \& Martos, 2009). Lopes-Costa and Munoz-Canavate (2015) assert that relational capital helps firms to obtain sustainable competitive advantages and consequently improve business performance. Spiritual capital, which creates belief and faith for religion (Ibn Khaldun, 1958), comprises religious viewpoints and ethical principles (Karatas, 2006). Ismail (2005) states that spiritual capital can develop firm performance. Technological capital encompasses of $R \& D$ and protection right. It contains technical knowledge i.e. the practice of production innovation methods and product technology that creates firm's competitive gains (Yilmaz \& Comez, 2016), thus transpire into a prevailing drive for high profitability.

\section{Ibn Khaldun's Economic Philosophy}

Ibn Khaldun wrote the Muqaddimah in 1377 that covers a substantial discussion of economics, sociology, education and political science. The scholar's insightfulness of economic philosophy and principles were very profound that a number of theories advocated by him (Mahdi, 2015). Ibn Khaldun is the first scholar in human history who has analytically examined the economic functions, specialization and foreign trade in economic surplus, the importance of technology, and government's role and its stabilization policies for increased output and employment. Specifically, Ibn Khaldun pioneered in classical economics (production, supply, demand, cost, consumption and utility) and modern economic theory.

Despite his contributions to economics, Adam Smith, whose tremendous works were published after 370 years of Ibn Khaldun's demise, was labelled as the Father of Economics by the West. In fact, the starting point of the theory of economic development is drawn to Ibn Khaldun (Hashim, Osman \& Alhabshi, 2015). It was Ibn Khaldun who initiated the novel ideas in various capacities of economic thought. What is more, Ibn Khaldun has made Shariah and principles of justice and morality the guiding philosophy of his theory of economic growth and development. Chapra (1999) recognized that Ibn Khaldun has espoused a dynamic interaction method to demonstrate exactly how the interconnected link of social, economic, moral, political, historical and demographical factors that affect the rise and fall of societies. Social, economic and organizational perspective of development is basically the positive achievement and response between the episteme of unity of knowledge and its social reform of the integrated world-system (Hudson, 1993). As such, sustainability and wellbeing are to be studied according to the principle and logic of complementariness. In view of that, the incorporation of those influences is regarded as the basis of sustainable competitive advantages and considered as the central focus of this study, especially in all IC components.

\section{Ibn Khaldun's Theory Development}

Ibn Khaldun's theory of development argues that the growth or decline of an economy does not depend on any one factor, but on the amalgamation of all factors (social, moral, economic, political and historical) (Al-Ghazali, 1993). The Muqaddimah has elaborated the eight principles (kalimat hikamiyyah) of political wisdom that entangled with mutual strength in a circular way (the starting or the ending is undifferentiated) (Edvinsson and Richtner, 1999). Ibn Khaldun stressed on the circled interaction of all socio-economic and political variables namely political authority (G), the Shariah (S), people (N), resources (W), development (g) and justice (j) in which each variable influences the others and is influenced by others. The analysis took almost 120 years or over three generations. 
Chapra (2008) has expressed Ibn Khaldun's model in an equation to describe about the relationship of each factor:

$$
\mathbf{G}=\mathbf{f}(\mathbf{S}, \mathbf{N}, \mathbf{W}, \mathbf{g} \text { and } \mathbf{j})
$$

G represents a dependent variable that denoted the development and decline of economy. The strength of an economy relies on the sturdiness of political authority. To be sustainable in the long run, the political authority must maintain the well-being of people $(\mathrm{N})$ by taking care of their surrounding which is susceptible to development (g) and justice (j) via the execution of the Shariah (S) and equitable distribution of resources (W).

Intrinsically, Ibn Khaldun's theory of development is a combination of the Classical and New development theories and the concerns on the costs of economic and business performance explicated by western economists plus the role of religion in supporting economic and business growth (Edvinsson \& Malone, 1997).

\section{Applying Ibn Khaldun's Theory Development of the IC Components in SMEs}

In term of human capital, natural talents and acquired skills are emphasized by Ibn Khaldun in his concept of free economy and freedom of choice. He proclaimed that to maximize man's level of satisfaction and earnings, there must be freedom in performing works according to man's talents and abilities. As a result, high quality products and more units of labour per hour will be produced (Khan, 2014). Intrinsically, besides acquiring skills and knowledge themselves, SME entrepreneurs should stimulate a culture in which knowledge is valued across their organizations. One way to do this is perhaps to encourage the employees to provide novel ideas in making the firm more profitable (Choudhury, 2012).

Nevertheless, in managing knowledge of the organization, SME entrepreneurs should also protect their organizational capital. Any intellectual property of their business has to be secured in order to avoid from competitors' imitation. Efficient systems for storing and retrieving information about products, services, systems, processes, brand, and research and development $(R \& D)$ must be preserved and secured. Ibn Khaldun envisages the collapse of business and economic activities when the property rights are not protected:

"When attacks (on property) are extensive and general, extending to all means of making a livelihood, business inactivity, too, becomes (general), because the general extent of (such attacks upon property) means a general destruction of the incentive (to do business). If the attacks upon of the property are light but the stop page of gainful activity was corresponding slightly" (Agil \& Razak, 2010).

In relational capital, Ibn Khaldun asserts on the collective responsibility and good relationships for the setting up of a just system and harmonious organization. Entrepreneurs and workforce are esteemed members of the general public who attempt to capitalize on the yield for their deeds in the kind of profits and wages. Ibn Khaldun stresses that profit is the major motivation for business and economic endeavor since it will bring about the expansion of production and constructive firm performance (Jardón \& Martos, 2009). Human beings are social creatures and favour of living together in a community. Depending on their capacity alone, individuals cannot satisfy all their basic needs or look after themselves. However, in a state of conflict, hostility ('udwan) and injustice ( $(\mathrm{ulm})$, it is impossible for them to have social life. Hence, 'asabiyyah (group feeling) and wazi' (detaining power or government) are crucial as to thwart fight and unfairness and to live together (Aminu, Mahmood \& Muharram, 2015).

Ibn Khaldun advocated on the implementation of Shariah (S) among people (N) in all worldly affairs (Fernandez, Montes \& Vasquez, 2008). Thus, SME entrepreneurs should possess spiritual capital so that they are free from all conducts that are harmful for business development such as dishonesty, fraud and injustice. As supported by Ahmad Azrin (2015), spiritual values are important to be added in any business activity especially the one that involves organizational corporate social responsibility. Likewise, Ibn Khaldun emphasized on the moral and material elevation of individuals $(\mathrm{N})$ who create the fundamental basis for the rise and fall of a society. Retaining spiritual capital creates development-friendly entrepreneurs, equipped with moral values (S), whose would generate a proper climate in a society and help increase business performance (Boulakia, 1971).

In term of technological capital, Ibn Khaldun's primacy of justice, life security and intellectual property protection promote positive values like honesty, hard work, integrity, capital accumulation, entrepreneurship and technological advancement (Chapra, 2008). A creative education system for independent thinking and behavior emerges from those inceptions. Ibn Khaldun's great support for education and research has influenced human ability, technological and intellectual enhancements that produce "momentous intellectual awakening" among various scholars (regardless of their fields and faiths) to join in without any discrimination (Chapra, 1999). 


\section{Conclusion}

Briefly, in his Economic Philosophy, Ibn Khaldun analyses and integrates all multidisciplinary factors that contribute to the development and decline of economy and business. An understanding to Ibn Khaldun's theory of development and its contribution to outstanding business performance assists SME entrepreneurs in managing IC effectively. Although he did not live in a modern world, Ibn Khaldun had provided a contemporary interpretation of economic and business development, as well as illuminated the concept of intellectual capital.

\section{Acknowledgement}

This study was supported by Universiti Teknologi MARA Cawangan Kelantan and Universiti Sultan Zainal Abidin. We would like to express our gratitude to Professor Masudul Alam Choudhury, Department of Shari'ah and Economics, AIS, Universiti Malaya and Dr. Syed Omar Syed Agil, former Professor of Universiti Tun Abdul Razak, for sharing their pearls of wisdom with us during the course of this study. Somehow, any errors in this paper are our own and should not tarnish the reputations of these esteemed people.

\section{References}

Agil, D.S.O.B.S. \& Razak Campus, K.L. (2010). Inaugural Professional Lecture (IPL).

Ahmad Azrin, A. (2015). The Missing Dimension of Corporate Social Responsibility (CSR) Measurement in Malaysian Islamic Banks. British Journal of Economics, Finance and Management Sciences, 10(1), 16-28.

Al-Ghazali, A. H. (1993). Imam Ghazali's Ihya ulum-id-din. (Karim, F. Trans.), Book 3, (1993) 7-51. Delhi: Nasri for Kitab Bhavan. Retrieved from https://ia601605.us.archive.org/35/items/IhyaUlumAlDinVol1/ Ihya\%20Ulum\%20Al\%20Din\%20Vol\%203.pdf

Aminu, M. I., Mahmood, R., \& Muharram, F. M. (2015). The Intangible Resources and Small Firms' Multilevel Performance: A Partial Least Squares Approach. Asian Social Science, 11(16), 187.

Bontis, N. (1999). Managing Organizational Knowledge by Diagnosing Intellectual Capital: Framing and advancing the state of the field. International Journal of Technology Management, 18, 5/6/7/8. 433- 462. https://doi.org/10.1504/IJTM.1999.002780

Bontis, N. (2004). National intellectual capital index: a United Nations initiative for the Arab region. Journal of Intellectual Capital, 5(1), 13-39. https://doi.org/10.1108/14691930410512905

Boulakia, J. D. C. (1971). Ibn Khaldûn: A Fourteenth-Century Economist. The Journal of Political Economy, 79(5), 1105-1118. https://doi.org/10.1086/259818

Chapra, M. U. (1999). Socioeconomic and political dynamics in Ibn Khaldun's thought. American Journal of Islamic Social Sciences, 16(4), 17.

Chapra, M. U. (2008). Ibn Khaldun's theory of development: Does it help explain the low performance of the present-day Muslim world?. The Journal of Socio-Economics, 37(2), 836-863. https://doi.org/10.1016/j.socec.2006.12.051

Choudhury, M. A. (2012). Reversing entropy to sustainability: the moral dimension. OIDA International Journal of Sustainable Development, 3(4), 67-84.

Cortini, M., \& Benevene, P. (2010). Interaction between structural and human capital in Italian NPO: leadership, organizational culture and human resource management. Journal of Intellectual Capital, 11(2), 123-139. https://doi.org/10.1108/14691931011039642

Edvinsson, L. \& Malone, M. (1997). Intellectual Capital: Realizing Your Company's True Value by Finding Its Hidden Brain-power. New York: Harper Collins: NY.

Edvinsson, L. \& Richtner, A. (1999). Words of value- giving words to IC. Skandia.

Fernandez, E., Montes, J. M., \& Vasquez, C. J. (2008). Typology and strategic analysis of intangible resources. A resource-based approach. Technovation, 20(2), 81-92. https://doi.org/10.1016/S0166-4972(99)00115-7

Hashim, M. J., Osman, I., \& Alhabshi, S. M. (2015). Effect of Intellectual Capital on Organizational Performance. Procedia-Social and Behavioral Sciences, 211, 207-214. https://doi.org/10.1016/j.sbspro.2015.11.085

Hitti, P. (1958). History of the Arabs. Macmillan, London

Hudson, W. (1993). Intellectual capital: How to build it, enhance it, use it. John Wiley: New York.

Ibn Khaldun. (1958). "The Muqaddimah”: An Introduction to History, trans. from Arabic by Franz Rosenthal, 3 
volume, Bollingen Series, 43 (New York: Pantheon, 1958).

Ismail, M. B (2005). The influence of intellectual capital on the performance of Telekom Malaysia. PhD Thesis. Universiti Teknologi Malaysia.

Jardón, C. M., \& Martos, M. S. (2009). Intellectual capital and performance in wood industries of Argentina. Journal of Intellectual Capital, 10(4), 600-616. https://doi.org/10.1108/14691930910996670

Karatas, S.C. (2006). Economic theory of Ibn Khaldun and rise and fall of nations. Bid, 2, 281.

Keenan, J. and Aggestam, M. (2001). Corporate governance and intellectual capital: Some conceptualizations, Blackwell Publisher Ltd., 9(4), 259-275.

Khalique, M., Bontis, N., Abdul Nassir bin Shaari, J., \& Hassan Md. Isa. (2015). A. Intellectual capital in small and medium enterprises in Pakistan. Journal of Intellectual Capital, 16(1), 224-238. https://doi.org/10.1108/JIC-01-2014-0014

Khalique, M., Isa, A. H. M., \& Shaari, J. A. N. (2013). Predicting the impact of intellectual capital management on the performance of SMEs in electronics industry in Kuching, Sarawak. IUP Journal of Knowledge Management, 11(4), 53.

Khan, M. W. J. (2014). Identifying the Components and Importance of Intellectual Capital in Knowledge-Intensive Organizations. Business and Economic Research, 4(2). https://doi.org/10.5296/ber.v4i2.6594

Lopes-Costa, J. A. \& Munoz-Canavate, A. (2015). Relational Capital and Organizational Performance in the Portuguese Hotel Sector (NUTS II Lisbon). Procedia Economics and Finance, 26, 64-71. https://doi.org/10.1016/S2212-5671(15)00839-4

Mahdi, M. (2015). Ibn Khaldun's Philosophy of History: A study in the Philosophic foundation of the science of culture. Routledge.

Malaysia Productivity Centre (MPC). (2014). Chapter 3: Raising Competitiveness through Labour Quality.

National Economic Advisory Council. (2010). New Economic Model for Malaysia Part 1: Strategic Policy Directions. National Economic Advisory Council. Putrajaya.

Omar, C. M. Z. C., \& Azmi, N. M. (2015). Factors Affecting the Success of Bumiputera Entrepreneurs in Small and Medium Enterprises (SMEs) in Malaysia. International Journal of Management Science and Business Administration, 1(9), 40-45. https://doi.org/10.18775/ijmsba.1849-5664-5419.2014.19.1004

Powell, W. W., \& Snellman, K. (2004). The knowledge economy. Annual review of sociology, 199-220. https://doi.org/10.1146/annurev.soc.29.010202.100037

Ramezan, M. (2011). Intellectual capital and organizational organic structure in knowledge society: how are these concepts related? International Journal of Information Management, 31(1), 88-95. https://doi.org/10.1016/j.ijinfomgt.2010.10.004

Saunders, J. J. (Ed.). (1966). The Muslim World on the Eve of Europe's Expansion. Prentice Hall, Englewood Cliffs, NJ.

Stewart, T. A. (1997). Intellectual capital: the new wealth of organizations. New York: Bantam Doubleday Dell Publishing Group: NY.

Sydler, R., Haefliger, S., \& Pruksa, R., (2014). Measuring intellectual capital with financial figures: Can we predict firm profitability? European Management Journal, 32(2), 244-259. https://doi.org/10.1016/j.emj.2013.01.008

Ullah, A. A., \& M Hassan Yousaf, B. (2016). IC in SMEs in Pakistan. Global Journal of Management and Business Research, 15(11).

Yilmaz, O., \& Comez, P. (2016). The Effect of Structural Capital on Enterprise (Qualitative and Quantitative) Performance. International Business Research, 9(6), 143. https://doi.org/10.5539/ibr.v9n6p143

\section{Copyrights}

Copyright for this article is retained by the author(s), with first publication rights granted to the journal.

This is an open-access article distributed under the terms and conditions of the Creative Commons Attribution license (http://creativecommons.org/licenses/by/4.0/). 